INTERNATIONAL JOURNAL OF MULTIDiscipLINARY RESEARCH AND ANALYSis

ISSN(print): 2643-9840, ISSN(online): 2643-9875

Volume 04 Issue 07 July 2021

DOI: 10.47191/ijmra/v4-i7-05, Impact Factor: 6.072

Page No.- $890-903$

\title{
Assessment of Incident of Road Traffic Accident along Yola Gombe Route
}

\author{
Innocent Reuben ${ }^{1}$, Yusuf Patrick Diwa ${ }^{2}$ \\ ${ }^{1,2}$ Office of the State Suveryor General. Adamawa State
}

ABSTRACT: Road traffic accident has become a prevalent and re-occurring phenomenon in Nigeria which constitutes a menace in modern times. Although all the developed and developing countries have suffer from various degrees of road accidents the developing countries clearly dominates with Nigeria having the second highest road accident among the 193 ranked countries of the world. This research aimed at identifying and assessing road accident hot spots between 2012 and 2016 along Yola/Gombe road. Data was collected from the accident hot spots using GIS/GPS techniques. The data was used to map out these accident hot spots. It also assessed the nature, mode of occurrence and types of injuries associated with the accidents within the study area. It further assesses the types and condition of the vehicle with the highest involvement in the accident within the study area.. GIS and Remote sensing method were used to analyse and georeference the map by throwing the coordinates of the accident hotspots that were picked and Data was also collected from Federal Road Safety Commission. These were analysed statistically. Result was used in this research. The study shows that between 2012 and 2016 about 2846 accidents were witnessed, 1,027 people died, 9017 people sustained various degrees of injuries and 3,384 vehicles were involved in the accidents. The causes of accident were observed. The preventive measures were suggested. The study recommended the need to seriously view road traffic regulations seeing them as human induced problem that demand an urgent attention. Such action is aimed at preventing untimely deaths, social, and economic losses and impacts on average Nigerians.

KEYWORDS: Accident, Road, GIS, Remote Sensing

\section{INTRODUCTION}

Road Traffic Accidents are the major causes of violent death in our contemporary society and also have high cost on the economy. Among all accidents, road traffic accidents claim the largest toll on human life and tend to be the most serious problem world over (Kuo, 2011). Worldwide, the number of people killed in Road Traffic Accidents (RTAs) each year is estimated at almost 1.5 million while the number of people injured could be as high as 50 million. Currently, Road Traffic Accidents rank 9th in order of causes of death and are projected to rank 3rd by the year 2020 (WHO, 2004).

Accident is defined as anything which happens by chance, anything occurring unexpectedly and un-designed (Odugbemi, 2010). Road traffic accident is a collision or similar incident involving a moving vehicle, resulting in property damage, personal injury or death (Astrom, Kent, Jovi, 2006). Road traffic accident is an unexpected phenomenon that occurs as a result of the use or operation of vehicles including bicycles and handcarts on the public highways and roads. Accidents may be fatal, resulting in deaths of the road users (passengers, drivers or pedestrians), or minor when it is not severe enough as to cause substantial hardship (Sarin, 2000)

Transportation problems faced by various nations have increased manifold, necessitating search for methods or alternatives that ensure efficient, safe, feasible and faster means of transport. A significant unexpected outcome of transportation systems is road accidents which result to injuries and loss of lives. (Sarin, 2000)

There is no universally accepted definition of a black spot. According to Hauer (1996) some researchers rank locations by accident rate (accidents per vehicle kilometres or per entering vehicles), some use accident frequency (accidents per km year or accidents per year) and some use a combination of the two. More recently, the proportion of accident types considered susceptible to treatment is also used for ranking. Another dimension of diversity in practice is that rank may be determined by the magnitude (either of rate or of frequency) or, as is more common, by the amount of the rate or frequency exceeds which is normal for such sites. 


\section{Assessment of Incident of Road Traffic Accident along Yola Gombe Route}

According to The Bureau of Transport and Regional Economics of Australia (2001) locations are in general classified as black spots after an assessment of the level of risk and the likelihood of an Accident occurring at each location. Sites with potentially hazardous features are sometimes described as grey spots. Based on survey by Sayed and Abdulwahab (1995), the number of accident is affected by three factors.

(i) The road environment

(ii) The condition of vehicles using the road system the skills and concentration

(iii) The physical state of road

This research considers some mechanical, human and environmental factor that causes accident.

In recent years, the number of studies using diverse tools for analyzing accidents and road design has increased considerably. Among these tools, Geographical Information Systems (GIS) and remote sensing stand out for their ability to perform complex spatial analyses. The advancements in GIS and GPS have been put to effective use in accident analysis. In addition to promoting linkage between various types of data and maps GIS is able to manipulate and visually display numerous types of data for easy comprehension. GIS is a technology for managing and processing location and related information. It visually displays the results of analyses thus enabling sophisticated analysis and quick decision making. Development of a system that uses GIS to analyze traffic accidents has been pursued towards improving the efficiency and effectiveness of traffic accident countermeasures. Also GIS would make analysis less time consuming and less tedious which otherwise would become very labour intensive. Thus GIS will offer a platform to maintain and update accident record database and use it for further analysis.

Road accidents do not simply happen, they are caused. Given the fact that Nigeria has the highest road accidents rate as well as the largest number of death per 10,000 vehicles, (Sheriff, 2009). There is the need to evaluate and map the areas where these accident are occurring in order to avert their occurrence.

Road Traffic Accidents are having a serious effect on our society and economy. Among all accidents, road traffic accidents claim the largest toll of human lives and tend to be the most serious problem worldwide (Kuo, 2011).The number of people killed in Road Traffic Accidents (RTAs) each year is seriously alarming and the number of people injured is also disturbing. Currently, Road Traffic Accidents has been ranked 9th in order of causes of death and are projected to rank 3rd by the year 2020 (WHO, 2004).

The pattern of road accidents in Nigeria seems to suggest that the better the road, the higher the accident and fatality rate as well as the severity and non-survival indices because of drivers" non-compliance with speed limits (Filani \& Gbadamosi, 2007). Studies have also shown that most accidents in Nigeria today occur on federal roads and the roads topping the list include BeninOre, Lagos-Ibadan Expressway, Abuja-Lokoja-Okene, Kaduna-Zaria-Kano, Okigwe-Umuahia, Kaduna-Abuja, Enugu-Awka-Onitsha and Otukpa among others (Godwin, 2012) In most of the studies carried out on Road Traffic Accidents in Nigeria, different methodologies were employed to examine the causes, pattern, trend and the effect of road traffic accident in Nigeria.

Although, none of these studies (Bennett, 2010; Rankavat and Tiwari, 2013; Aworemi and Abdul-Azeez 2010; Aderamo 2012; and Umar 2009) have attempted to analyze Road Traffic Accident hotspots between Yola and Gombe expressway in particular or assessing the nature of road accident. Therefore this study intends to assess road traffic accident between Yola and Gombe using various GIS techniques.

The aim of this research is to identify and assess road traffic accident hot spots between 2012 and 2016 along Yola to Gombe with the view of finding lasting solution to the accident problem. The aim of this study was achieved through the following objectives:

To map road traffic accident hotspot along trunk A road between Yola and Gombe from 2012-2016.

- $\quad$ To assess the mode, nature of occurrence and type of injuries associated with road accident along this area.

- $\quad$ To assess the types and condition of vehicles that have the highest involvement in accident along this road.

- To create an alternative route that will be cost effective and safer for road users.

\section{MATERIAL AND METHOD}

This study covers a total length of 230 kilometers. It is a federal road and is located between Yola and Gombe. Yola is located on latitude $09^{\circ} 14^{\prime} \mathrm{N}$ and $9^{\circ} 20^{\prime} \mathrm{N}$ and longitude $12^{\circ} 25^{\prime} \mathrm{E}$ and $12^{\circ} 28^{\prime} \mathrm{E}$. and Gombe is situated between latitude $10^{\circ} 15^{\prime} \mathrm{N}$ and $10^{\circ} 25$ longitude $11^{\circ} 10^{\prime} \mathrm{E}$ and $11^{\circ} 16$ of the Greenwich meridian (figure 1 ).

The study area comprises of sedimentary deposit within the rift and volcanic. The sedimentary deposits occupy the rift that runs eastward from Kaltungo area. The rift accumulated sediment of different strata graphic units which were involved in two deformation episodes during Cenomanian and Santonian ages that lead to distended structures of Lamurde, Gwonba-Tambo, Bagale-Gagare and Kiriwari anticlines lying adjacent to Dadiya ,Burong, Girei, and Fufore syncline alternatively. The unit formed 


\section{Assessment of Incident of Road Traffic Accident along Yola Gombe Route}

the Kiriwari, Bagale and Gagare hills. The second unit of deposit is Yolde formation. It consists of ancient beach deposit of cenomanian age and outcrop extensively around Lafiya Lamurde area.

The major vegetation in the states is savannah vegetation type, which is dominated by guinea savannah and Sudan savannah.

The data used for this study include: Google Earth imagery with spatial resolution of $1 \mathrm{~m}$ was acquired and route for the study area was extracted. GPS was used to collect the coordinates of the accident locations. The DEM of the study area was extracted from shuttle radar topographic mission data using ArcGIS version 10.1 was used to create the relief map using the 3D analyst tool. Accident record from Federal Road Safety Commission. The data collected include the following:

a) Date of accident

b) Location/route of accident

c) Number of vehicle involved

d) Type of vehicles involved

e) Type of accident (fatal, severe or minor)

f) Causes of accident

g) Number of people involved in the accident

The data from the Federal Road Safety Commission, the coordinates of the accident and the characteristics of the road was used for creation of the database.

The instrument used are: ArcGIS 10.1(for cartographic modelling), Microsoft Word (for word processing), Microsoft Excel ( for data presentation of charts),Hand held Germin GPS for data capturing/collection ,Colour printer (for colour graphics),Scanner( for data input) and PC System.

\section{RESUILTS AND DISCUSSIONS}

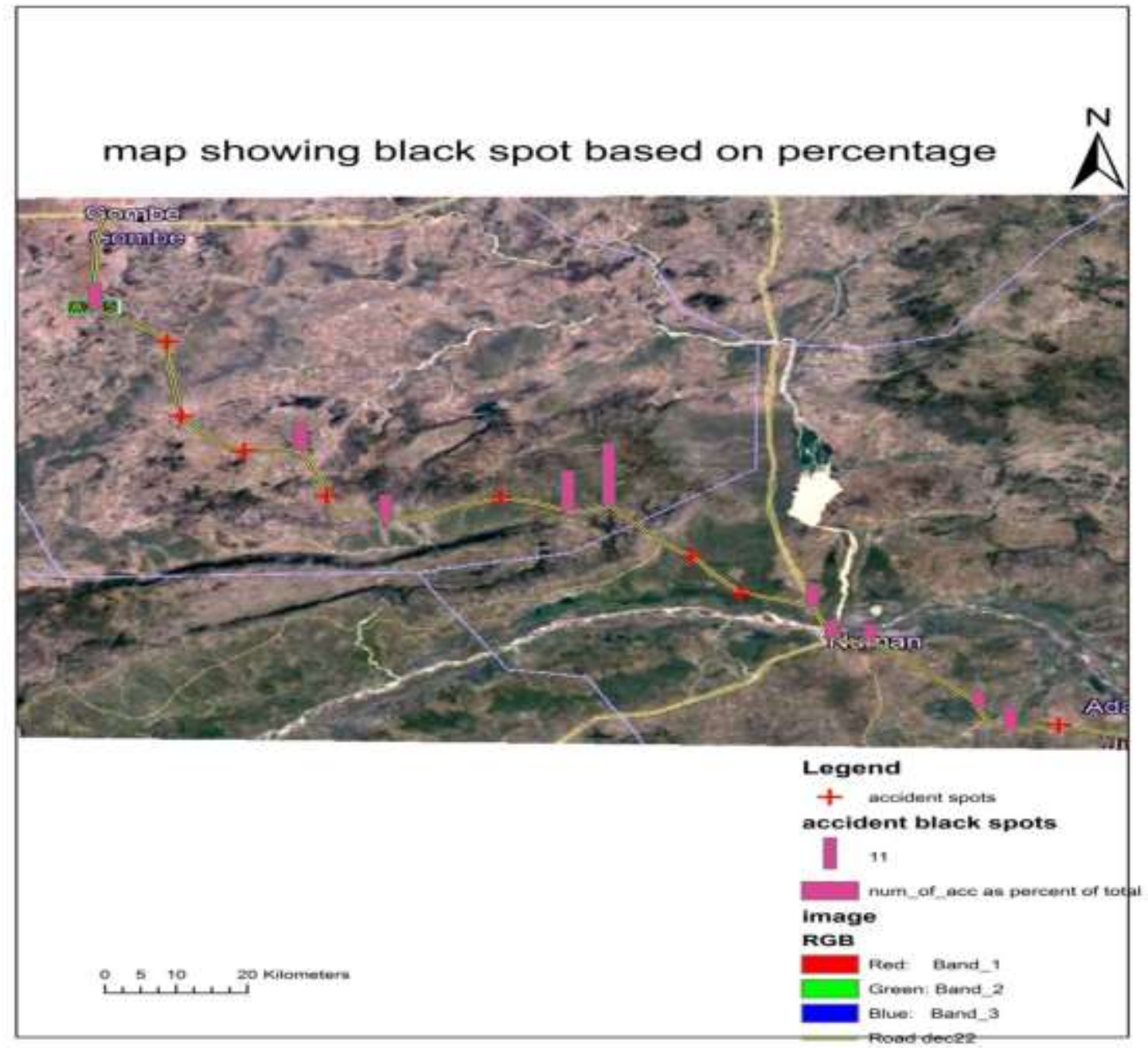

Fig.1.map showing accident black spots

Source: Author's work 


\section{Assessment of Incident of Road Traffic Accident along Yola Gombe Route}

Table 1.total accident record from 2012-2016

\begin{tabular}{|l|l|l|l|l|l|l|}
\hline YEARS & 2012 & 2013 & 2014 & 2015 & 2016 & Total \\
\hline RTC & 708 & 684 & 541 & 443 & 465 & 2841 \\
\hline KILLED & 196 & 226 & 217 & 183 & 205 & 1027 \\
\hline INJURED & 1929 & 2318 & 1876 & 1387 & 1507 & 9017 \\
\hline $\begin{array}{l}\text { VEHICLE } \\
\text { INVOLVED }\end{array}$ & 620 & 400 & 881 & 715 & 768 & 3384 \\
\hline
\end{tabular}

Source: Federal Road Safety Head Quarter Adamawa State

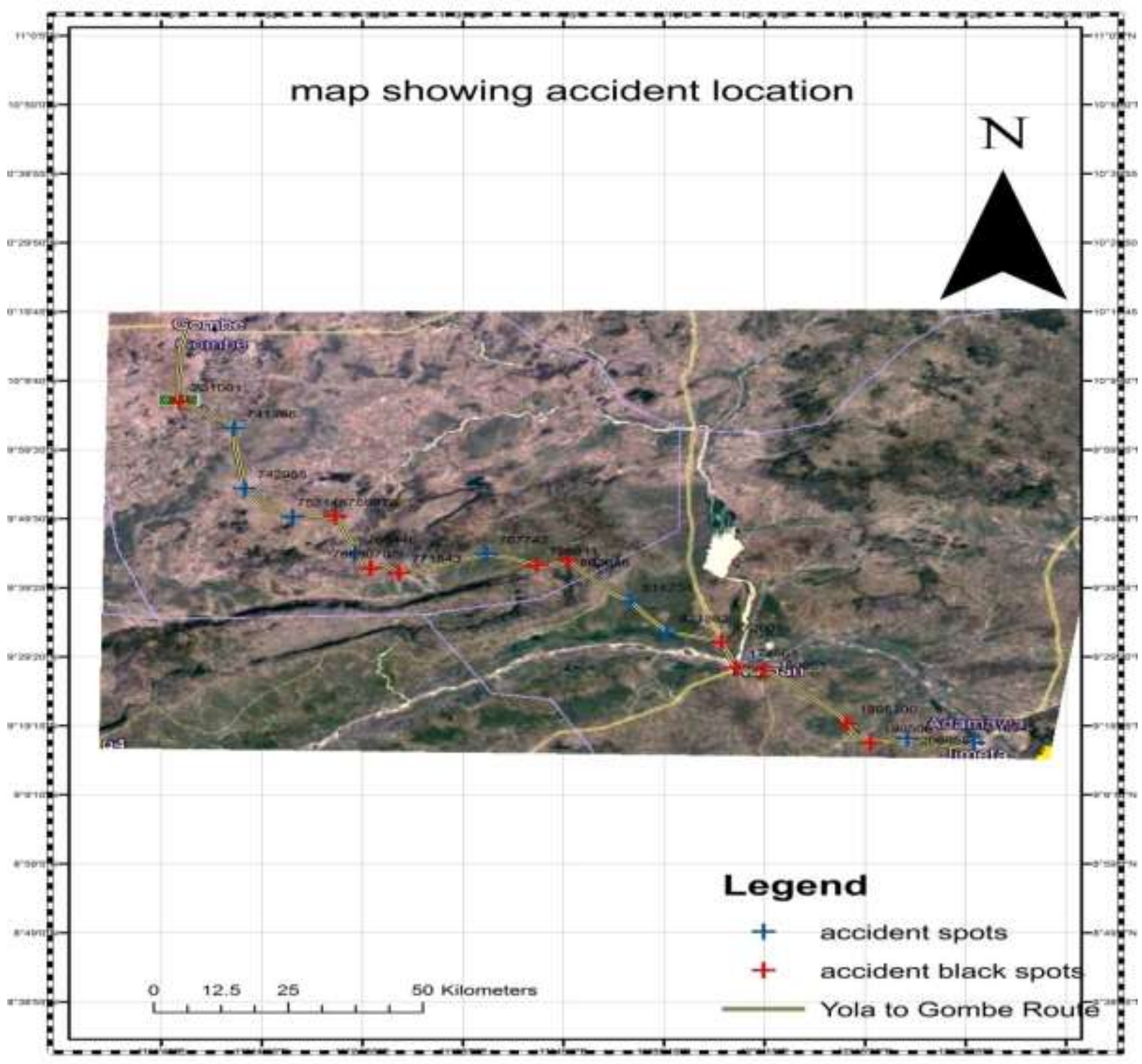

Fig2. Map showing accident location

Kernel density analysis

Kernel density analysis is used to find the accident probability zone by using accident hot spot information. The probability zones are classified into High, Medium, and Low. It displays the dangerous zone in red Colour 


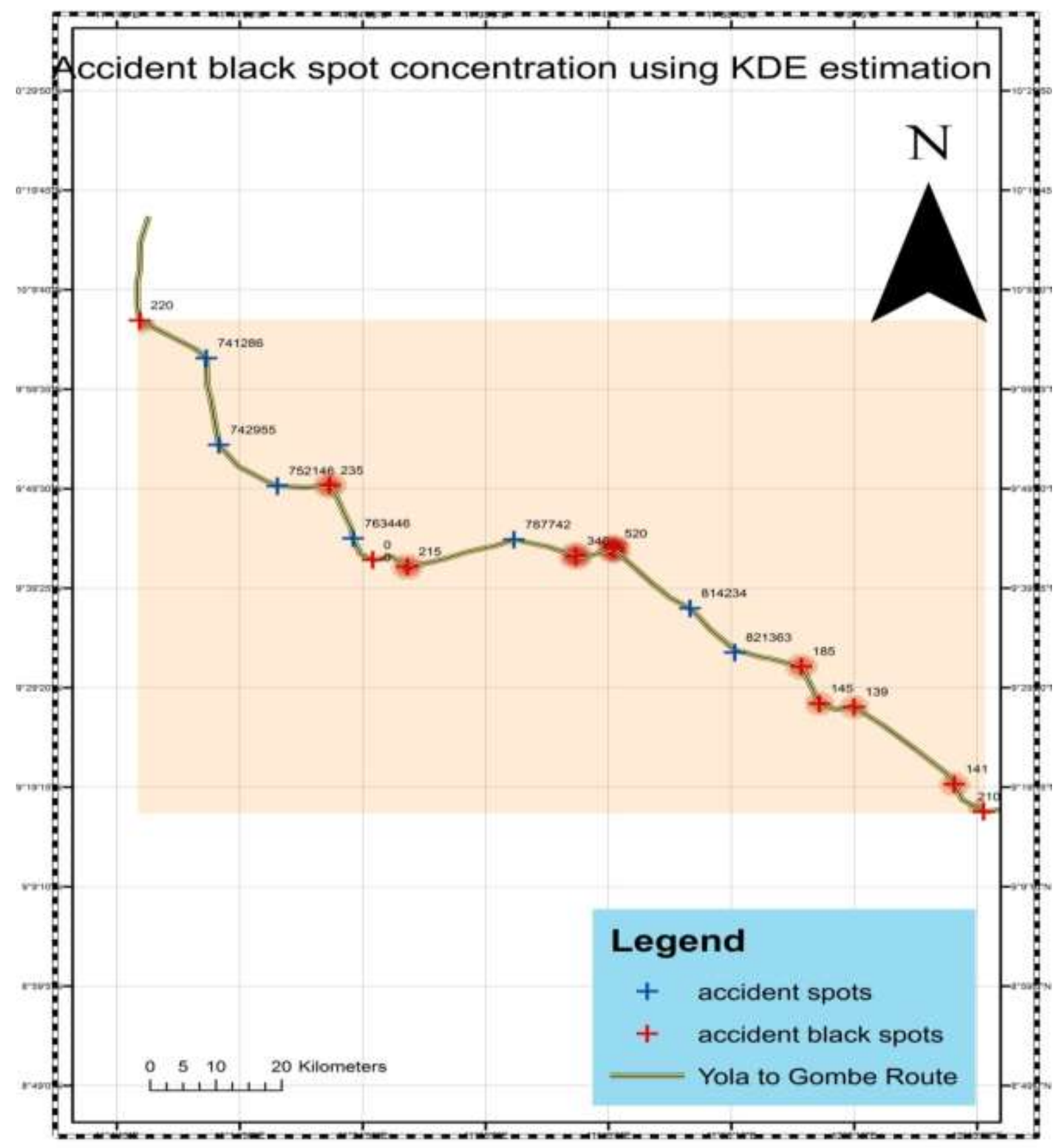

Fig.3. map showing areas of high concentration of accident using KDE

Source: Author' work 2017

Table.2. accident record of 2012

\begin{tabular}{|l|l|l|l|l|}
\hline 2012 (month) & T/ACC & KILLED & INJURED & V/INVOLVES \\
\hline JAN & 41 & 13 & 108 & 60 \\
\hline FEB & 60 & 10 & 117 & 68 \\
\hline MARCH & 69 & 16 & 150 & 77 \\
\hline APRIL & 103 & 25 & 208 & 117 \\
\hline MAY & 72 & 17 & 185 & 76 \\
\hline JUNE & 42 & 14 & 110 & 34 \\
\hline JULY & 56 & 21 & 138 & 46 \\
\hline AUGUAST & 52 & 16 & 151 & 38 \\
\hline SEPT & 39 & 10 & 118 & 23 \\
\hline
\end{tabular}


Assessment of Incident of Road Traffic Accident along Yola Gombe Route

\begin{tabular}{|l|l|l|l|l|}
\hline OCT & 64 & 17 & 206 & 34 \\
\hline NOV & 55 & 8 & 198 & 31 \\
\hline DEC & 55 & 29 & 240 & 16 \\
\hline TOTAL & 708 & 196 & 1929 & 620 \\
\hline
\end{tabular}

Source: Federal Road Safety Head Quarter Adamawa State

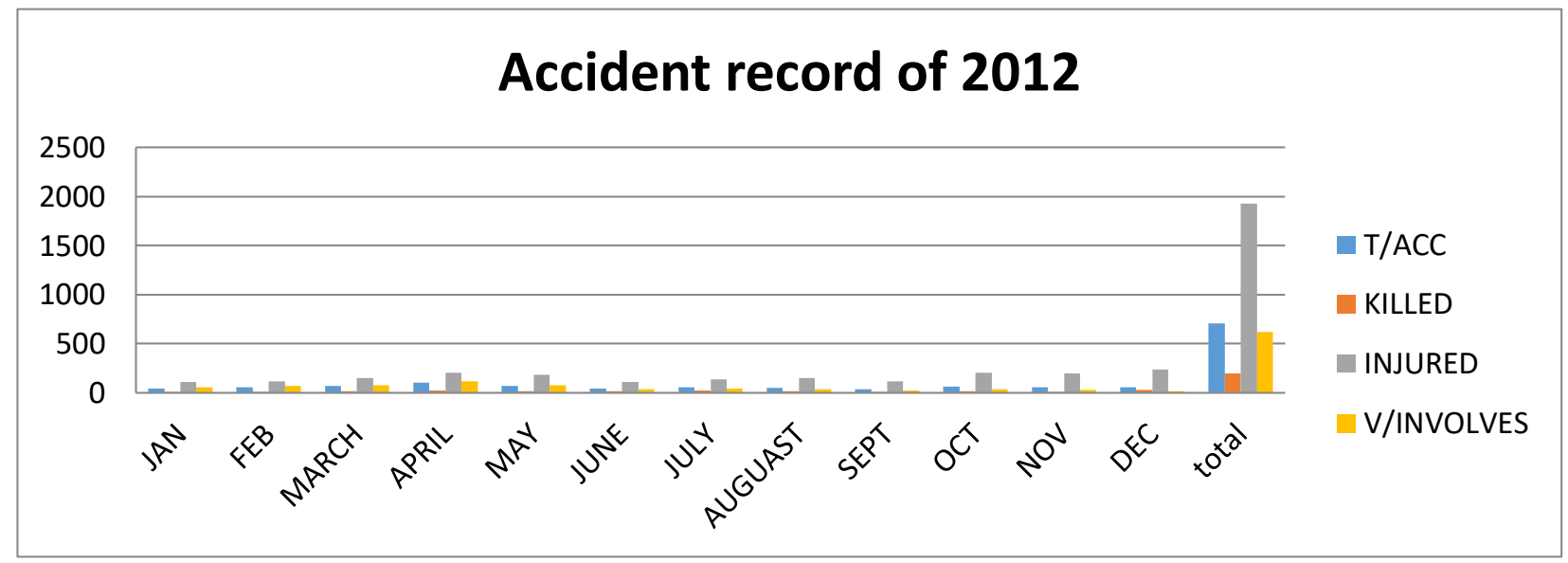

Fig.4 Graph showing 2012 accident record

Table 4. Accident record of 2013

\begin{tabular}{|l|l|l|l|l|}
\hline 2013 (months) & T/ACC & KILLED & INJURED & V/INVOLVES \\
\hline JAN & 47 & 27 & 223 & 33 \\
\hline FEB & 57 & 9 & 191 & 38 \\
\hline MARCH & 57 & 20 & 169 & 33 \\
\hline APRIL & 59 & 17 & 203 & 37 \\
\hline MAY & 63 & 24 & 193 & 20 \\
\hline JUNE & 43 & 12 & 123 & 25 \\
\hline JULY & 58 & 10 & 169 & 36 \\
\hline AUGUAST & 57 & 13 & 161 & 34 \\
\hline SEPT & 58 & 24 & 187 & 44 \\
\hline OCT & 52 & 15 & 188 & 34 \\
\hline NOV & 53 & 14 & 149 & 28 \\
\hline DEC & 80 & 41 & 362 & 38 \\
\hline TOTAL & 684 & 226 & 2318 & 400 \\
\hline
\end{tabular}

Source: Federal Road Safety Quarter Adamawa State

\section{Accident record of 2013}

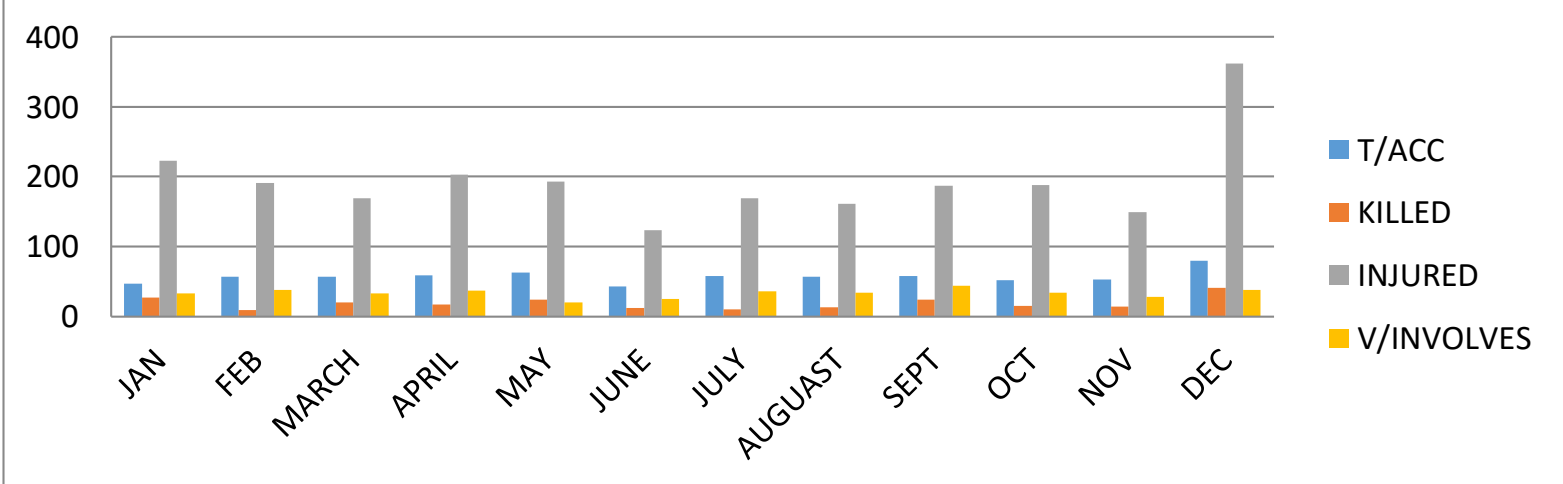

Fig.5.Graph showing accident record of 2013 


\section{Assessment of Incident of Road Traffic Accident along Yola Gombe Route}

Table 5. Accident record of 2014

\begin{tabular}{|l|l|l|l|l|}
\hline 2014(months) & T/ACC & KILLED & INJURED & V/INVOLVES \\
\hline JAN & 75 & 26 & 245 & 102 \\
\hline FEB & 45 & 29 & 201 & 61 \\
\hline MARCH & 43 & 24 & 95 & 64 \\
\hline APRIL & 30 & 4 & 52 & 49 \\
\hline MAY & 52 & 22 & 178 & 82 \\
\hline JUNE & 41 & 18 & 156 & 76 \\
\hline JULY & 23 & 4 & 65 & 41 \\
\hline AUGUAST & 52 & 20 & 203 & 84 \\
\hline SEPT & 39 & 13 & 116 & 63 \\
\hline OCT & 53 & 19 & 175 & 95 \\
\hline NOV & 44 & 19 & 195 & 82 \\
\hline DEC & 49 & 19 & 195 & 82 \\
\hline TOTAL & 546 & 217 & 1876 & 881 \\
\hline
\end{tabular}

Source: Federal Road Safety Quarter Adamawa State

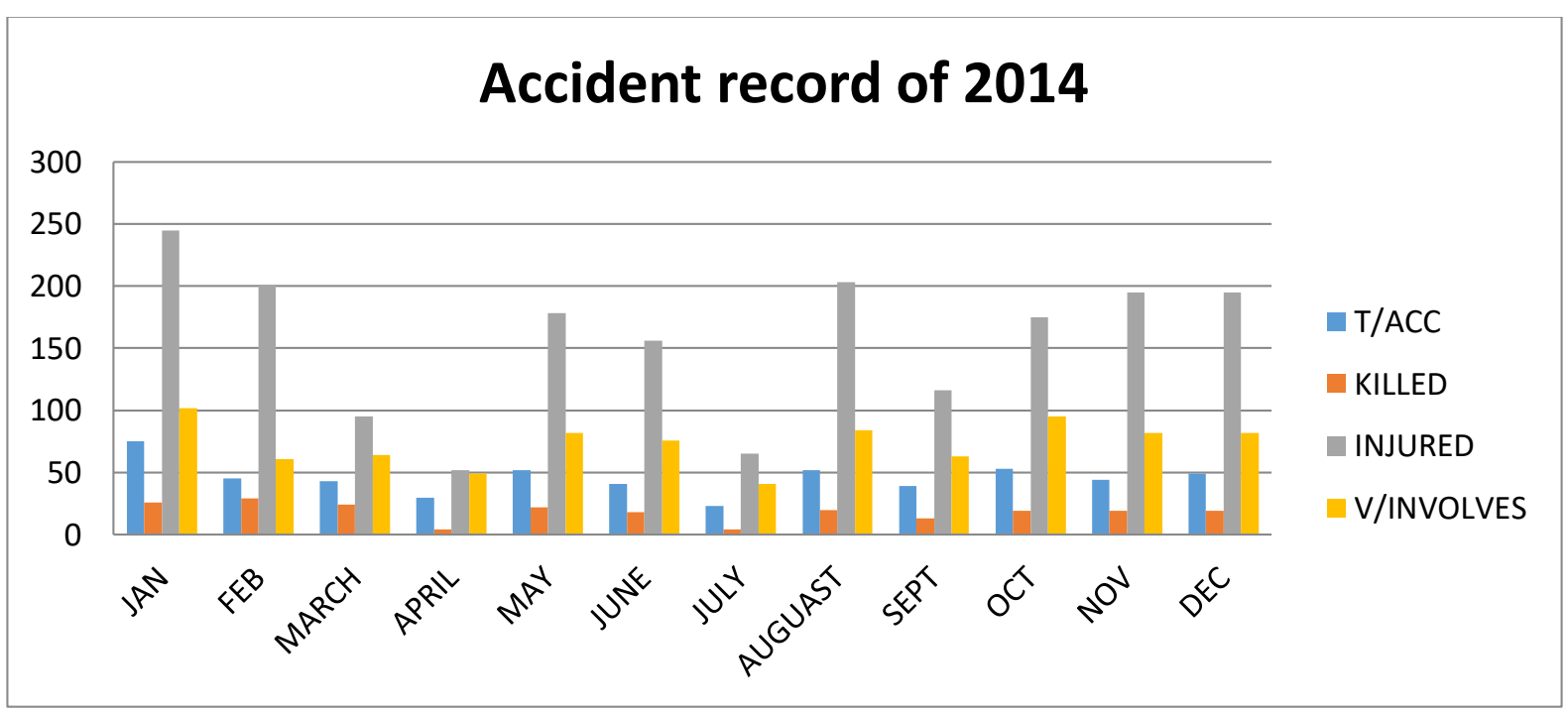

Fig 6.Graph showing accident record of 2014

Table 6.Accident record of 2015

\begin{tabular}{|l|l|l|l|l|}
\hline 2015(months) & T/ACC & KILLED & INJURED & V/INVOLVES \\
\hline & & & & \\
\hline JAN & 32 & 4 & 83 & 50 \\
\hline FEB & 28 & 23 & 129 & 56 \\
\hline MARCH & 44 & 10 & 139 & 75 \\
\hline APRIL & 31 & 15 & 93 & 48 \\
\hline MAY & 42 & 8 & 157 & 66 \\
\hline JUNE & 29 & 18 & 65 & 46 \\
\hline JULY & 29 & 13 & 76 & 47 \\
\hline AUGUAST & 34 & 8 & 85 & 47 \\
\hline SEPT & 38 & 26 & 130 & 59 \\
\hline OCT & 44 & 19 & 116 & 72 \\
\hline NOV & 42 & 19 & 101 & 72 \\
\hline DEC & 50 & 20 & 213 & 77 \\
\hline TOTAL & 443 & 183 & 1387 & 715 \\
\hline
\end{tabular}

Source: Federal Road Safety Quarter Adamawa State 


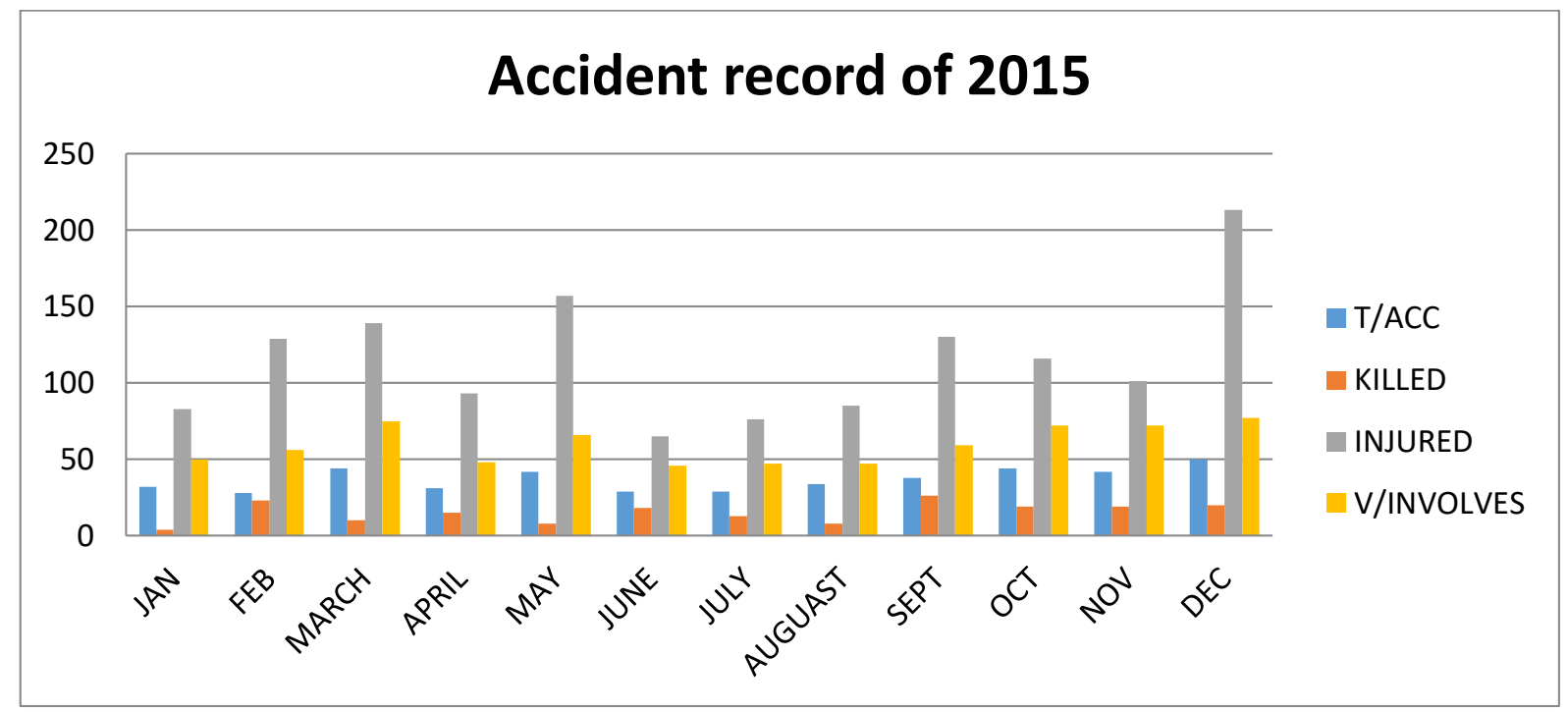

Fig 7.Graph showing accident record of 2015

Table 7. Accident record of 2016

\begin{tabular}{|l|l|l|l|l|}
\hline 2016 (months) & T/ACC & KILLED & INJURED & V/INVOLVES \\
\hline JAN & 47 & 25 & 177 & 89 \\
\hline FEB & 46 & 49 & 145 & 79 \\
\hline MARCH & 42 & 8 & 95 & 65 \\
\hline APRIL & 32 & 12 & 93 & 47 \\
\hline MAY & 41 & 6 & 150 & 64 \\
\hline JUNE & 33 & 13 & 103 & 53 \\
\hline JULY & 30 & 11 & 90 & 52 \\
\hline AUGUAST & 33 & 9 & 92 & 55 \\
\hline SEPT & 34 & 8 & 132 & 54 \\
\hline OCT & 36 & 11 & 98 & 56 \\
\hline NOV & 40 & 5 & 100 & 72 \\
\hline DEC & 51 & 48 & 232 & 82 \\
\hline TOTAL & 465 & 205 & 1507 & 768 \\
\hline
\end{tabular}

Source: Federal Road Safety Quarter Adamawa State

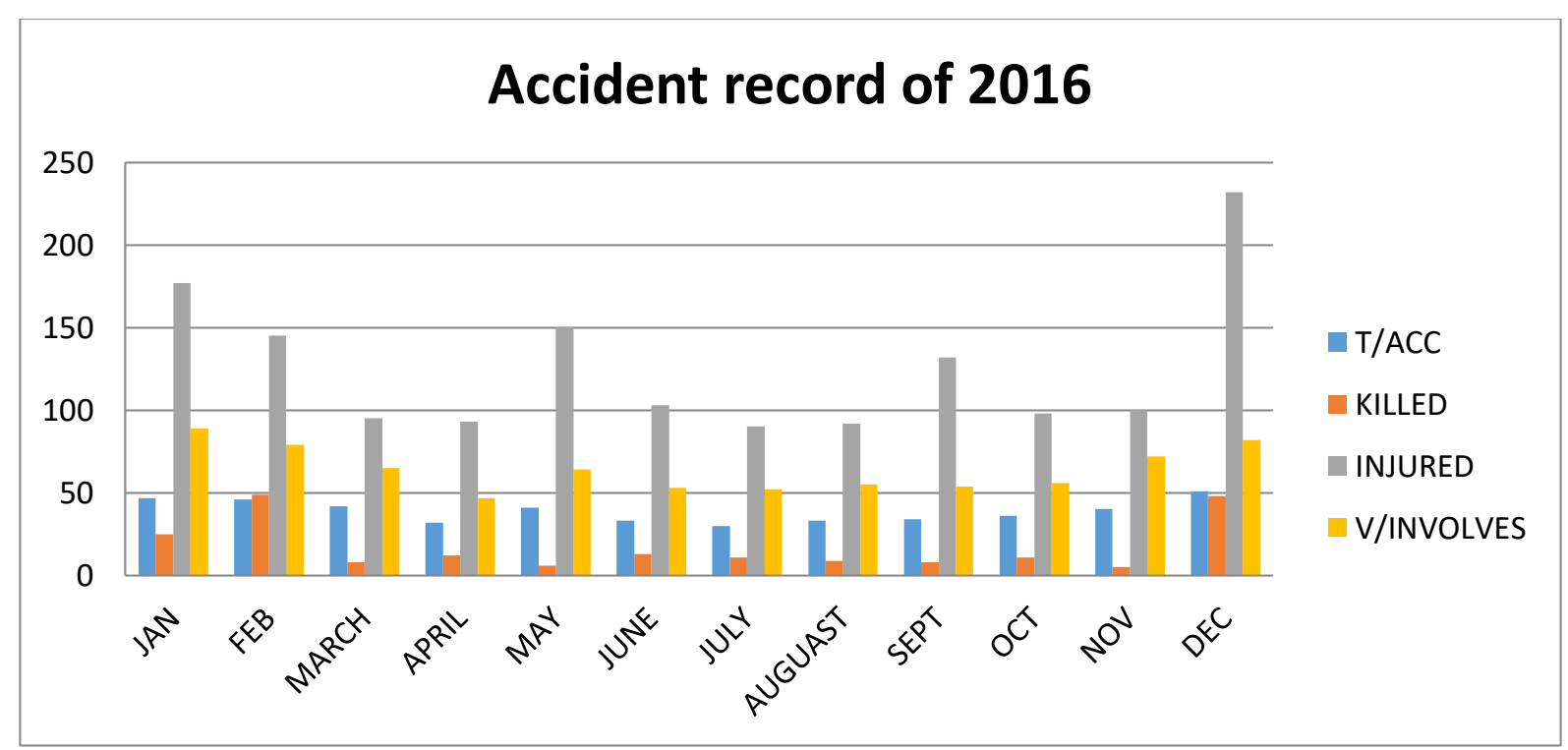

Fig 9. Graph showing accident record of 2016 


\section{Assessment of Incident of Road Traffic Accident along Yola Gombe Route}

\section{ANALYSIS OF NATURE OF ACCIDENT}

On the basis of the data collected total of 10461 accidents had occurred. Deaths, injuries have taken recorded. It is observed that nearly $52.481 \%$ injuries are grievous, Fatal (Death) accident recorded is (9.817\%), minor injuries is $37.707 \%$, based on the recorded at least 17 people died every month. These figures clearly show that number and accidents occurring between Yola to Gombe route are high. There is an urgent need to carry out proper traffic management studies in order to regulate the accident rate. Further, it can be seen that most accident prone area are as a result bends, and the steepness of the terrain In the last 5 years, total of 10461 accidents of different types have occurred. Out of this, 10461 accidents have lead to grievous injuries (52.481\%).

Table 10.showing record of Nature of accident from 2012-2016

\begin{tabular}{|l|l|l|l|l|l|l|}
\hline Nature of accident & 2012 & 2013 & 2014 & 2015 & 2016 & total \\
\hline Fatal & 196 & 226 & 217 & 183 & 205 & 1027 \\
\hline Grievous & 1406 & 1183 & 1097 & 809 & 995 & 5490 \\
\hline Minor injuries & 940 & 1135 & 779 & 578 & 512 & 3944 \\
\hline total & 2542 & 2544 & 2093 & 1570 & 1712 & 10461 \\
\hline
\end{tabular}

Source: Federal Road Safety Quarter Adamawa Stat

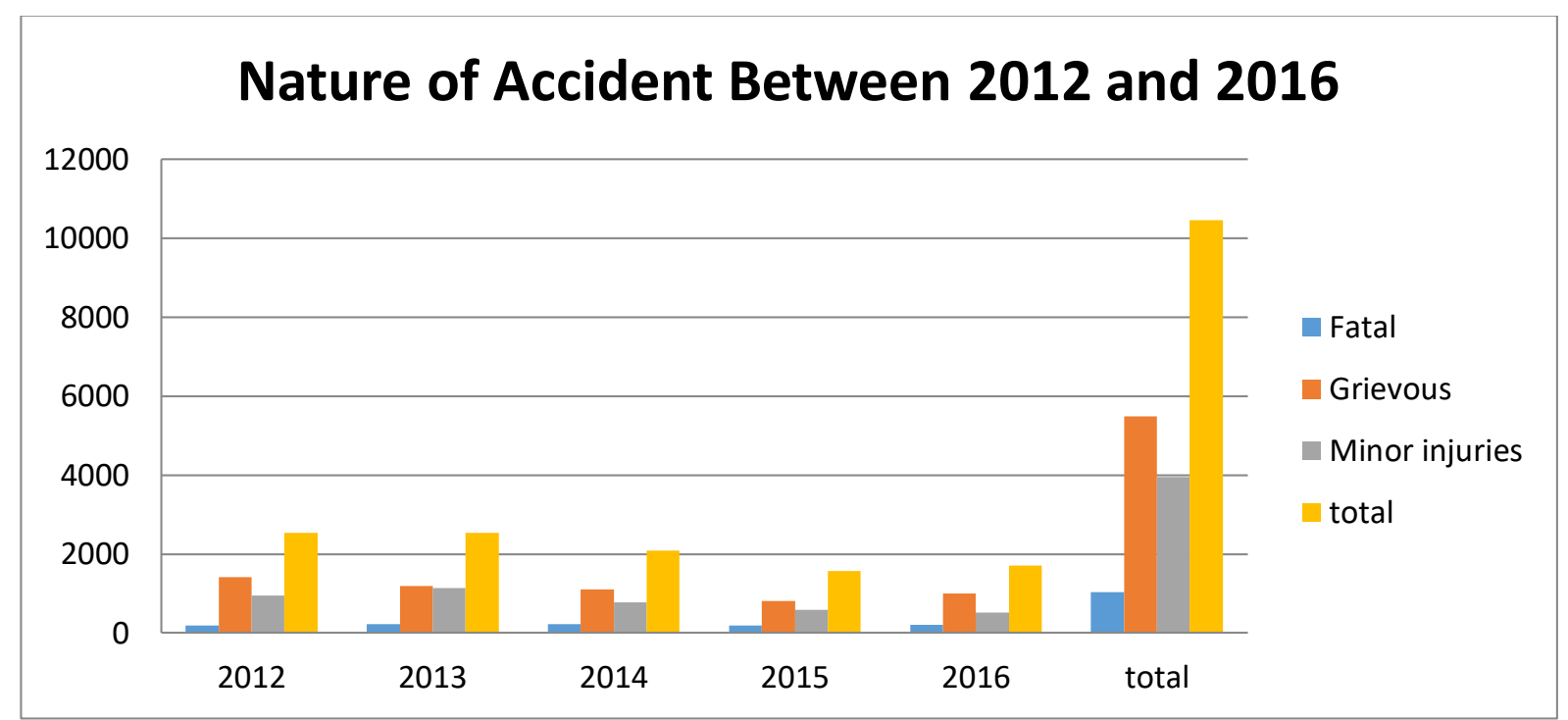

Fig 10.Graph of Nature of accident from 2012-2016

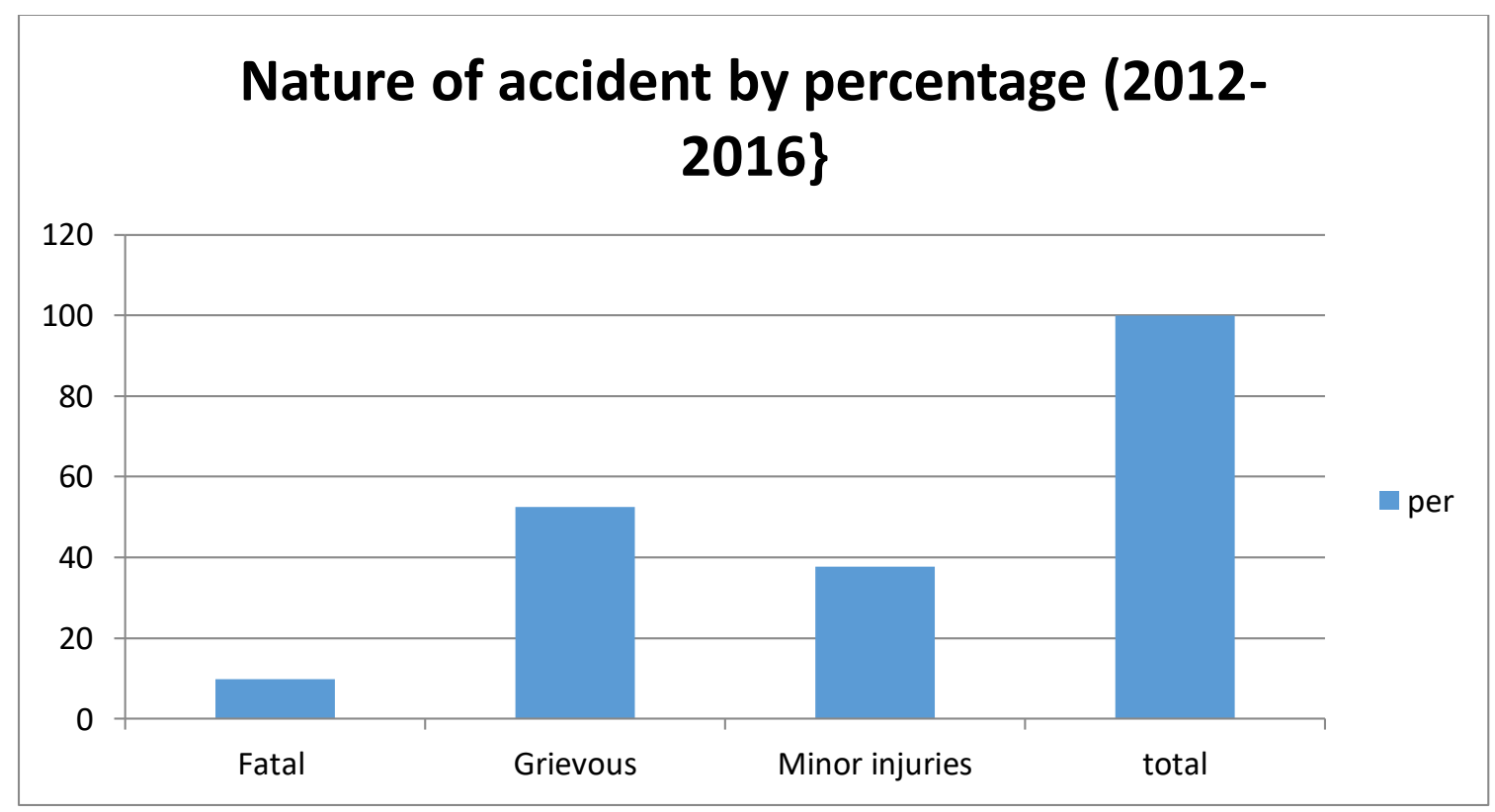

Fig 11.Graph of Nature of accident by percentage from 2012-2016 


\section{Assessment of Incident of Road Traffic Accident along Yola Gombe Route}

Based on the recorded data bad road had caused the highest number of accident to about (34.72\%), reckless driving caused (28.92\%), inexperience (13.98\%), mechanical fault (13.53\%), pedastrial crossing(5.62\%), unknown causes(3.23\%).

Table12. Record of causes of accident from 2912-2016

\begin{tabular}{|l|l|l|l|l|l|l|}
\hline Causes of accident & 2012 & 2013 & 2014 & 2015 & 2016 & total \\
\hline $\begin{array}{l}\text { Reckless } \\
\text { driving }\end{array}$ & 195 & 182 & 178 & 152 & 116 & 823 \\
\hline Inexperience & 110 & 98 & 66 & 51 & 73 & 398 \\
\hline Mechanical fault & 92 & 76 & 71 & 81 & 65 & 385 \\
\hline $\begin{array}{l}\text { Pedestrian } \\
\text { Crossing }\end{array}$ & 40 & 50 & 23 & 20 & 27 & 160 \\
\hline Bad road & 250 & 236 & 201 & 130 & 171 & 988 \\
\hline Unknown causes & 21 & 42 & 7 & 9 & 13 & 92 \\
\hline total & $\mathbf{7 0 8}$ & $\mathbf{6 8 4}$ & $\mathbf{5 4 6}$ & $\mathbf{4 4 3}$ & $\mathbf{4 6 5}$ & $\mathbf{2 8 4 6}$ \\
\hline
\end{tabular}

Source: Federal Road Safety Quarter Adamawa State

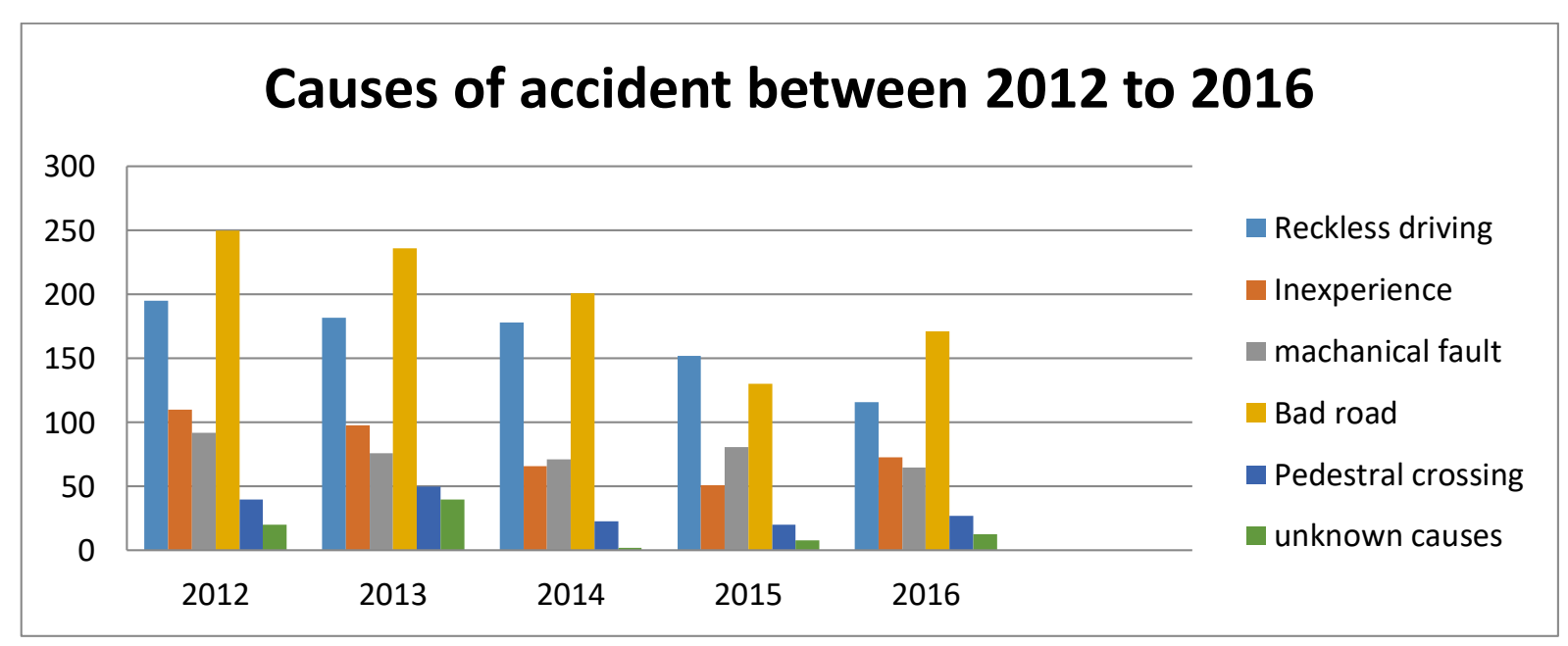

Fig 12.Graph showing causes of accident from 2012-2016

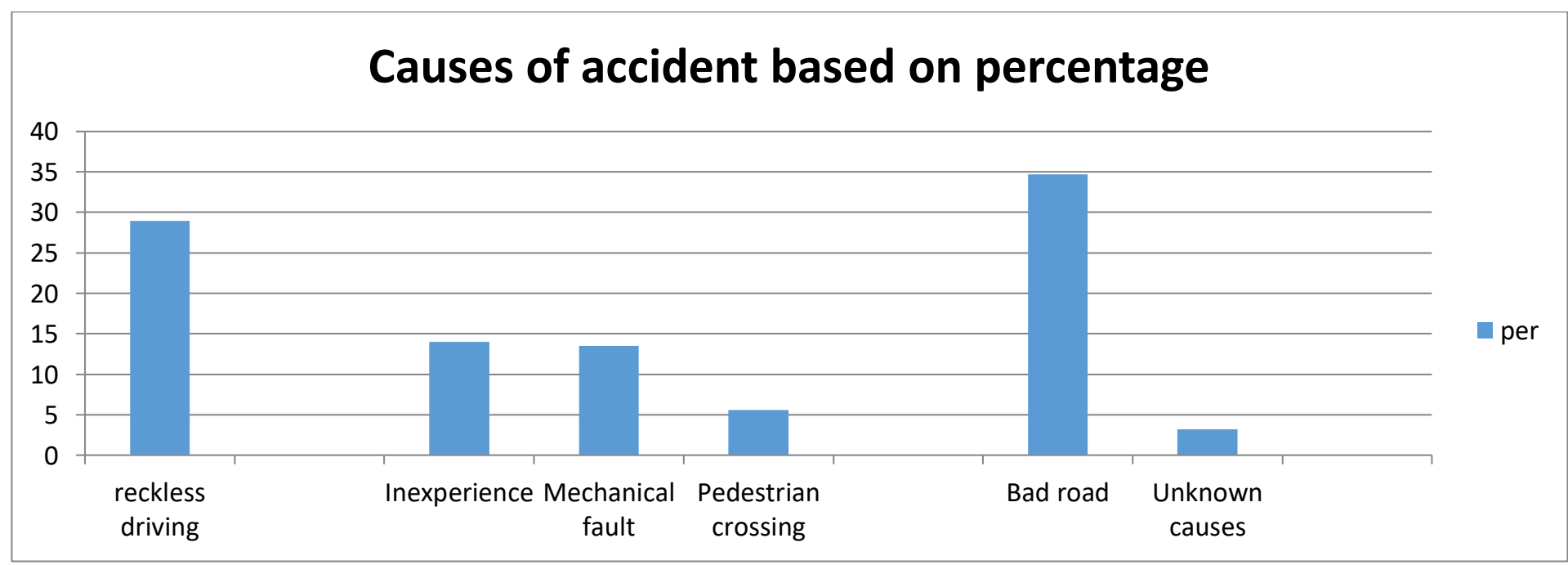

Fig 13.showing causes of accident based on percentage

Table 13.Total accident record from 2012-2016

\begin{tabular}{|l|l|l|l|l|l|l|}
\hline years & 2012 & 2013 & 2014 & 2015 & 2016 & Total \\
\hline T/A & 708 & 684 & 546 & 443 & 465 & 2846 \\
\hline
\end{tabular}


Assessment of Incident of Road Traffic Accident along Yola Gombe Route

\begin{tabular}{|l|l|l|l|l|l|l|}
\hline KILLED & 196 & 226 & 217 & 183 & 205 & 1027 \\
\hline INJURED & 1929 & 2318 & 1876 & 1387 & 1507 & 9017 \\
\hline VEHICLE INVOLVED & 620 & 400 & 881 & 715 & 768 & 3384 \\
\hline
\end{tabular}

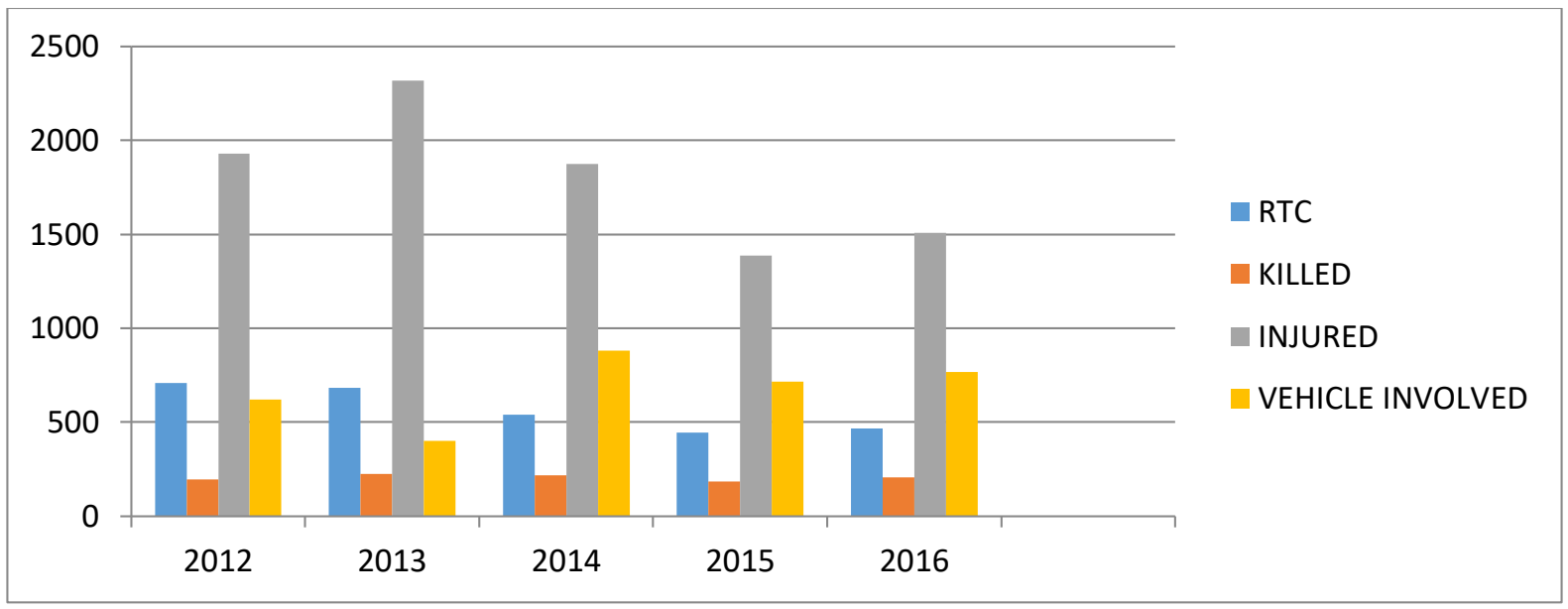

Fig14.Graph showing total record of accident of 2012 to 2016

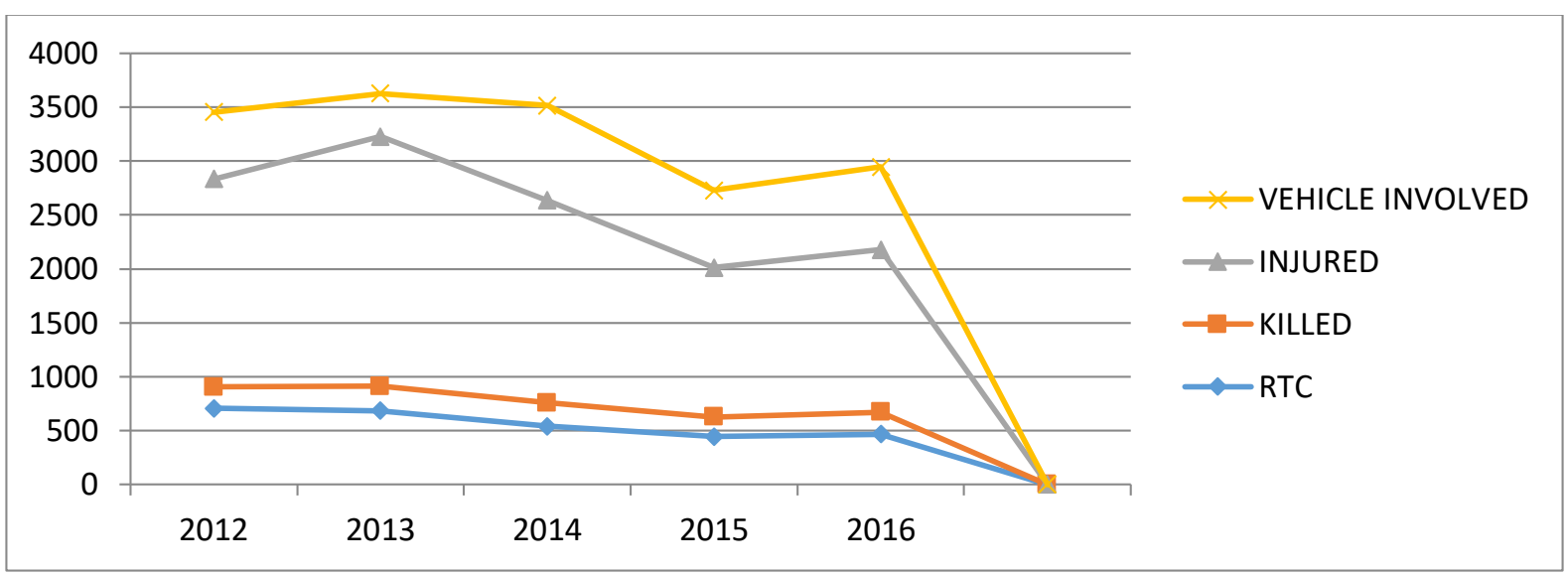

Accident Analysis on Monthly Basis:

Here the database has been queried for accidents as per month for the year 2012-2016 using ARC GIS. This query

Yield results for accidents occurring in each month for the years2012-2016. It is clearly seen that the maximum number of accidents occurred at Yola to Gombe route in the months of December. This could be due to large number of vehicles travelling for charismas and New Year celebration. Also in the months of December, February and January the fatality rate is high especially in December followed by February and January in all the five period of years.

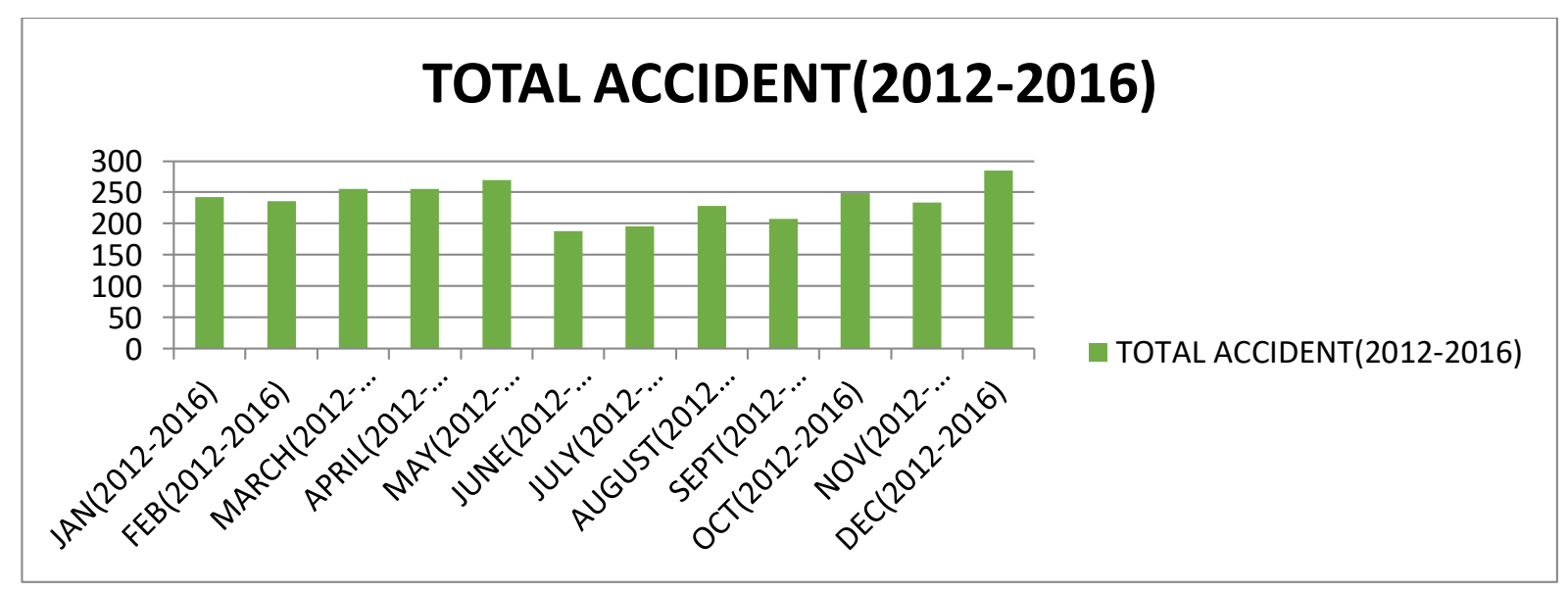

Fig 15. Total Accident record from 2012-2016 


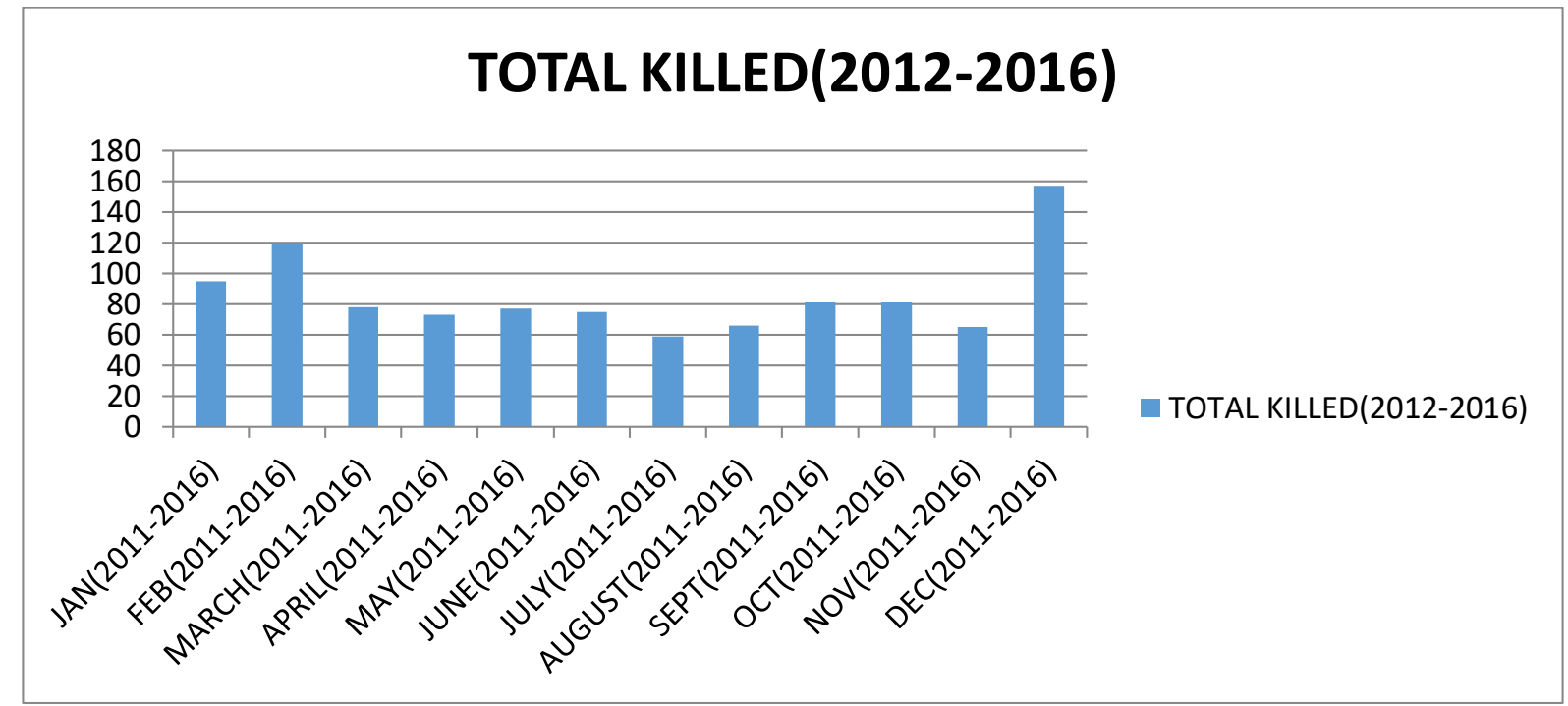

Fig 16. Graph of total people killed by accident from 2012-2016

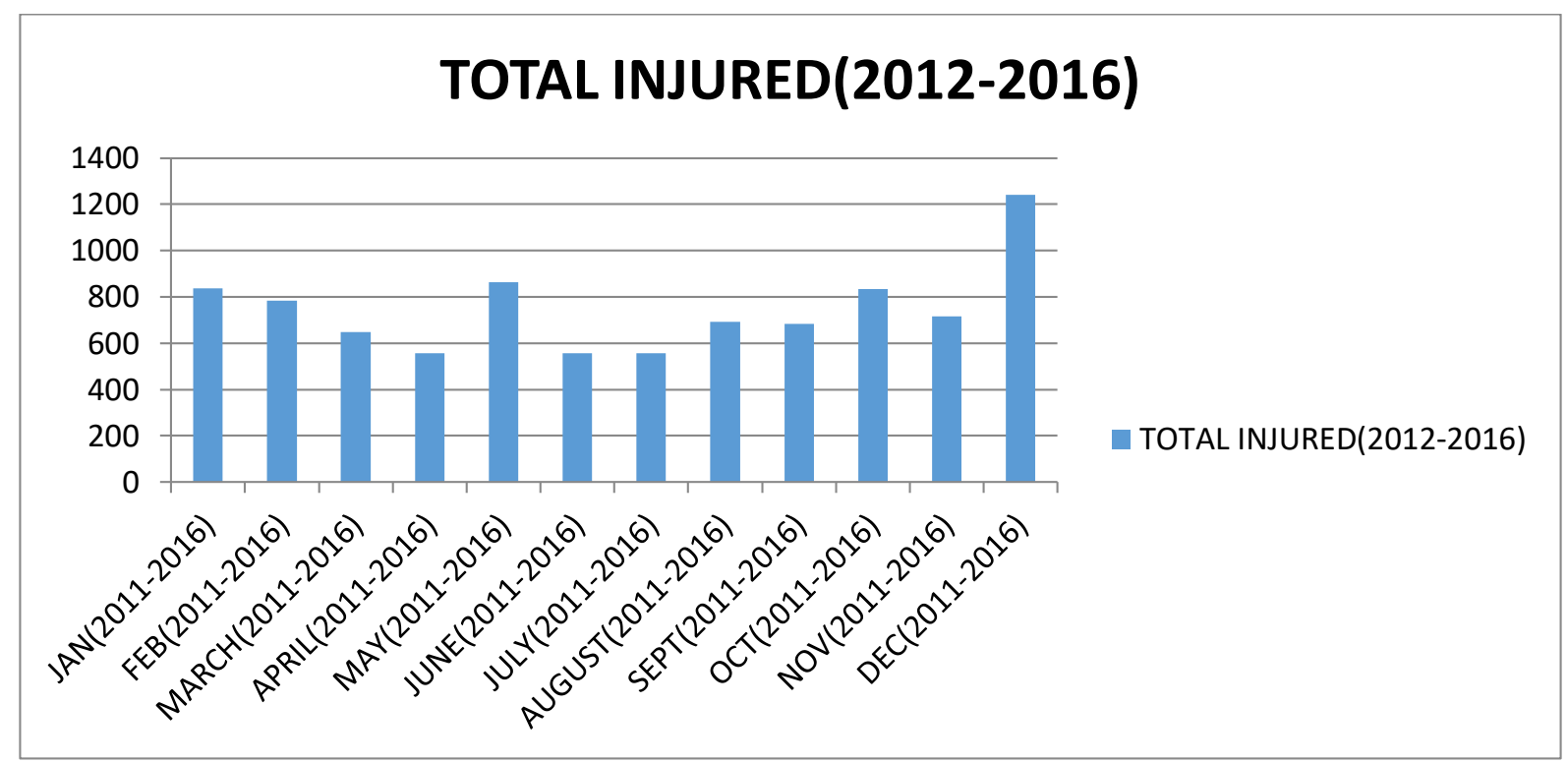

Fig 16.Grph of total people injured from 2012-2016

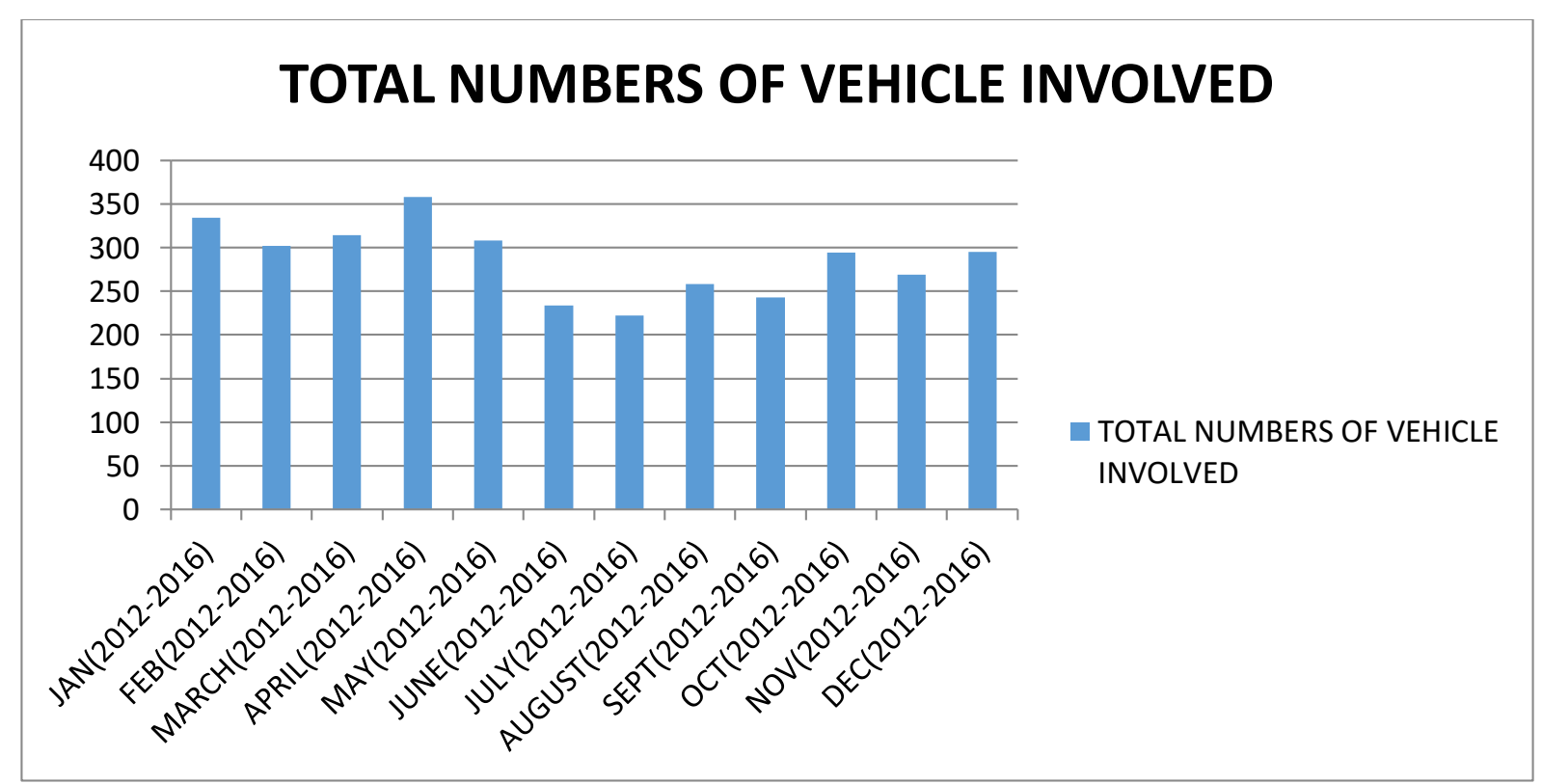

Fig 17.Graph of total vehicle involved in the accident from 2012-2016 


\section{Assessment of Incident of Road Traffic Accident along Yola Gombe Route}

\section{Analysis accidents based on type of vehicle}

The query to the database is performed using type of vehicle involved in accidents. The vehicles have been classified into four categories

- Bus: i.e. hummer bus, litace bus costar bus etc

- Lorries: i.e. thriller, tipper

- Starlet: i.e. Toyota starlet, golf,

- $\quad$ Others: i.e. jeep, Camry, Mercedes bens etc

It can be clearly seen that bus type of vehicles are more involved in accidents as compared to other Vehicles followed by Lorries. This is due to the fact that most drivers of such vehicles are inexperience and the nature of the road is bad and lake of enough traffic signs on the road.

Table 18. Showing the types of vehicle involved in the accident from 2012-2016

\begin{tabular}{|l|r|r|r|r|r|r|}
\hline Types of vehicle & 2012 & 2013 & 2014 & 2015 & 2016 & Total \\
\hline Bus & 238 & 160 & 318 & 291 & 317 & 1324 \\
\hline Lorries & 180 & 142 & 283 & 260 & 288 & 1153 \\
\hline Starlet & 150 & 60 & 231 & 143 & 131 & 715 \\
\hline others & 52 & 38 & 30 & 16 & 32 & 168 \\
\hline Total & 620 & 400 & 862 & 710 & 768 & 3360 \\
\hline
\end{tabular}

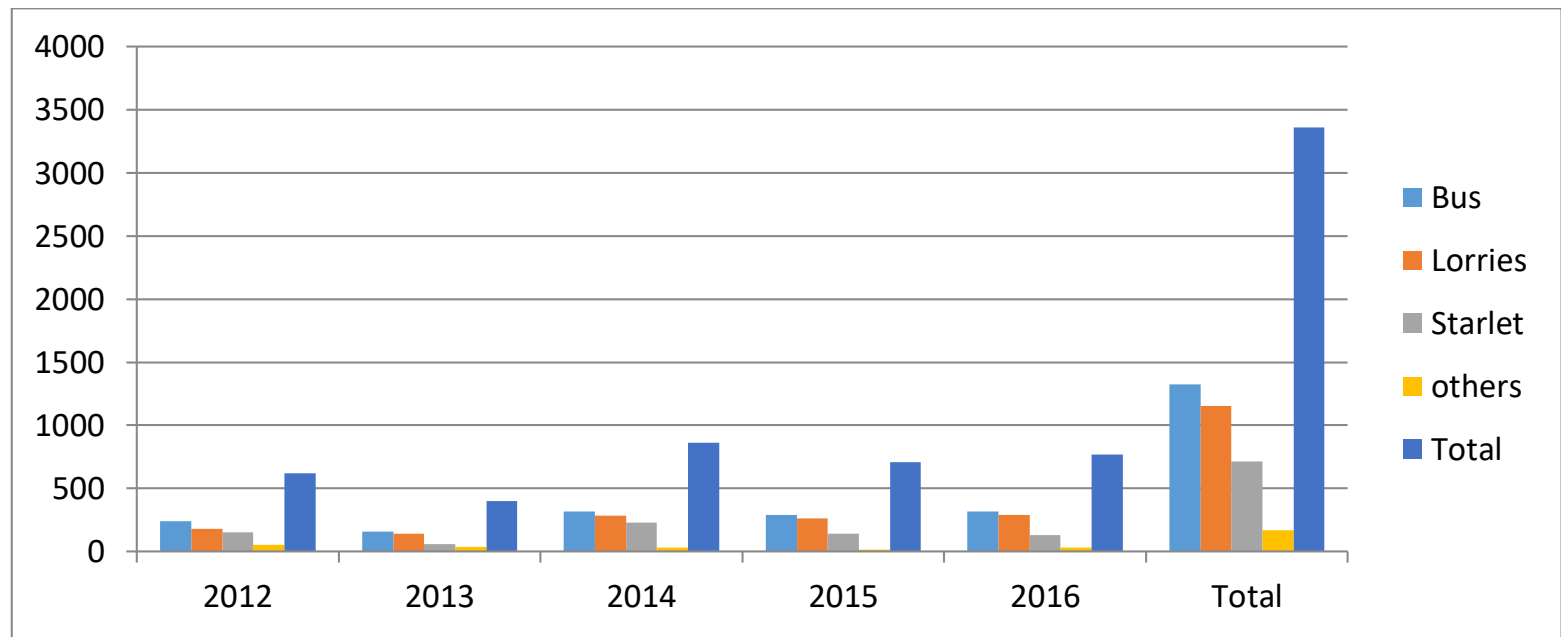

Fig 18.types of vehicles involved in accident from 2012-2016

\section{CONCLUSION AND RECOMMENDATION}

Guarding against the causes of road traffic accident is a collective affair as it affects everyone directly or indirectly. Haven identified some of the remote and immediate causes of road traffic accidents in Nigeria, here are some of the suggested preventive measures if well adopted and practiced, will go a long way towards reducing and curtailing road traffic accidents in Nigeria To mitigate these challenges leading to road traffic accidents in Nigeria, roads must be widened and well maintained with traffic free zones created; inter-sections and road signals must be improved upon; there must be freeway bottlenecks removal initiatives; there must also be special event management strategies in place; while traffic signals, lightings and signage must be improved; parking policy, park and ride facilities and end of year congestion management strategies must be developed and put in place and traffic rules and regulations must be observed.

\section{REFERENCES}

1) Astrom P, Kenr S,and Jovi T (2006). Spatial analysis of fatal and injury crashes in Pennsylvania. Accident Analysis \& Prevention, 38(3), pp. 618-625.

2) Barnett, S.\& Gale, T., (1998). GIS based process helps TransCanada select best route for expansion line. Oil Gas J. 96 (25), $63-71$. 


\section{Assessment of Incident of Road Traffic Accident along Yola Gombe Route}

3) Falani A, Gbadomosi D (2007). A GIS-based Bayesian approach for analyzing spatial- temporal patterns of intra-city motor vehicle crashes. Journal of Transport Geography,15(4),pp. 274-285.

4) Hauer,Z (2014). "Statistical Test of Difference between Expected Accident Frequencies "Transportation Research Record No. 1542 Safety and Human Performance/Statistical Methods and Accident Analysis for Highway and Traffic Safety, Transportation Research Board/National Research Council, National Academy Press, Washington, D.C., 1996, pg. 24-29.

5) Kuo, A. (2011). Geographical Information Systems aided traffic accident analysis system case study: city of Afyonkarahisar. Accident Analysis \& Prevention, 40(1), pp. 174-181.

6) Odugbemi, O. O. (2010). Road Transportation and Tourism in Nigeria, Joja Press, Lagos.

7) Rankavat, S. \& Tiwari, G., (2013). Pedestrian Accident Analysis in Delhi using GIS. Journal of the Eastern Asia Society for Transportation Studies, 10(0), pp. 1446- 1457

8) Sarin, S.M., (1998), - Road Traffic Safety in Indian Issues and Challenges Ahead\|l, Indian Highways, Vol. 26, No.6., pp 2638.

9) Sheriff, (2007), Assessment of Noise level due to vehicular traffic at Warangal city, India/l, International Journal of Environment and Pollution/l, Vol 30. No.1, pp.137-153

10) Umar, M (2009). Bad Drainage and its Effects on Road PavementConditions in Nigeria. Http://elotitv.com/entry/road-accidents-more-causes-for-alarm-1. Snapshot of the page as it appeared on 12 Nov2013 04:03:33 GMT

11) WHO, (2013): WHO Road traffic injuries: fact sheet $N^{\circ} 358$ March, 2013 http://www.who.int/mediacentre/factsheets/fs358/en/ 